\title{
Combined effect of green tea and Ganoderma lucidum on invasive behavior of breast cancer cells
}

\author{
ANITA THYAGARAJAN ${ }^{1}$, JIASHI ZHU² and DANIEL SLIVA ${ }^{1,3,4}$ \\ ${ }^{1}$ Cancer Research Laboratory, Methodist Research Institute, 1800 N Capitol Ave., E504, Indianapolis, IN 46202; \\ ${ }^{2}$ Clinical Pharmacology, Pharmanex Research Institute, Provo, UT 84601; ${ }^{3}$ Department of Medicine, and \\ ${ }^{4}$ Indiana University Cancer Center, School of Medicine, Indiana University, Indianapolis, IN, USA
}

Received November 6, 2006; Accepted December 22, 2006

\begin{abstract}
Epidemiological studies have suggested that consumption of green tea may decrease the risk of a variety of cancers. In addition, mushroom Ganoderma lucidum has been used for the promotion of health, longevity and treatment of cancer in traditional Chinese medicine. In the present study we show that extract from green tea (GTE) increased the anticancer effect of G. lucidum extract (GLE) on cell proliferation (anchorage-dependent growth) as well as colony formation (anchorage-independent growth) of breast cancer cells. This effect was mediated by the down-regulation of expression of oncogene c-myc in MDA-MB-231 cells. Although individual GTE and GLE independently inhibited adhesion, migration and invasion of MDA-MB-231 cells, their combination demonstrated a synergistic effect, which was mediated by the suppression of secretion of urokinase plasminogen activator (uPA) from breast cancer cells. Our study suggests the potential use of combined green tea and G. lucidum extracts for the suppression of growth and invasiveness of metastatic breast cancers.
\end{abstract}

\section{Introduction}

Breast cancer is the leading cause of cancer death among women of 20-59 years old and contributed to one third of newly diagnosed cases of breast cancer in the United States in 2005 (1). The low incidence of breast cancers among Asian women was associated with dietary behavior, suggesting the preventative effect of nutrition against cancer (2). Although inconclusive, epidemiological studies suggested the importance of different nutritional/natural products for cancer prevention. However, while important, these studies are highly correlative

Correspondence to: Dr D. Sliva, Cancer Research Laboratory, Methodist Research Institute, $1800 \mathrm{~N}$ Capitol Ave., E504, Indianapolis, IN 46202, USA

E-mail:dsliva@clarian.org

Key words: adhesion, colony formation, proliferation, invasion, c-Myc, uPA, EGCG, MDA-MB-231, Reishi mushroom because they are usually focused only on one nutritional product. For example, the consumption of green tea was correlated to the prevention of a variety of cancers (3), and an inverse correlation between mushroom intake and risk of gastric cancer was described (4).

Carcinogenesis is a multistage overlapping process consisting of initiation, promotion and progression phases. Initiation starts when normal cells are exposed to a carcinogen, which results in genomic DNA damage (5). Promotion is characterized as clonal proliferation of damaged cells and formation of preneoplastic focal lesions. Finally, progression produces a new clone of tumor cells with increased proliferative capacity, invasive behavior and metastatic potential (5). Therefore, some natural/dietary compounds demonstrated strong potential in the inhibition of different stages of carcinogenesis and their effectiveness is currently being evaluated as non-toxic chemopreventative agents with possible chemotherapeutic activity (6). Nevertheless, the combination or mixture of different natural/dietary products could enhance the effect of isolated compounds, and could reflect dietary behavior.

Extracts from an oriental medicinal mushroom Ganoderma lucidum has been used in traditional Chinese medicine for the prevention or treatment of a variety of diseases. G. lucidum is currently consumed in the form of tea, powder or extract as a dietary supplement. Furthermore, in vivo animal studies demonstrated inhibition of hepatoma, sarcoma, and lung and colon cancers in mice by G. lucidum extracts containing a variety of biologically active compounds, including B-glucanbased polysaccharides and lanostane-type triterpenes (7-11). In addition, we have recently demonstrated in vitro that an extract from G. lucidum inhibits the proliferation and invasive behavior of highly metastatic breast cancer cells through the suppression of $\mathrm{Akt} / \mathrm{NF}-\kappa \mathrm{B}$ signaling, which resulted in the down-regulation of expression of cyclin D1, Cdk4 and urokinase-plasminogen activator (UPA) in breast cancer cells (12-14). Tea, from the plant Camellia sinensis, belongs to the most globally consumed beverages (3). Moreover, green tea and especially its major biologically active compound (-)epigallocatechin-3-gallate (EGCG) also demonstrated cancer chemopreventative effects in different cancer models $(15,16)$. The biological mechanism of the chemopreventative effects of EGCG was linked to the modulation of multiple signaling pathways finally resulting in the down-regulation of expression 
of AP-1 and NF- $\mathrm{-B}$ regulated genes (3). In addition, we have recently demonstrated that green tea extract containing $50 \%$ of EGCG induced cell cycle arrest and suppressed the invasive behavior of breast cancer cells through the inhibition of AP-1 and NF-кB signaling (17). The present study was undertaken to evaluate the effect of combination of green tea and G. lucidum extracts on the growth and invasive behavior of breast cancer cells.

\section{Materials and methods}

Materials. G. lucidum extract (GLE, ReishiMax ${ }^{\mathrm{GLp}}$ ), containing $13.5 \%$ polysaccharides and $6 \%$ triterpenes, and green tea leaf extract (GTE, Tegreen ${ }^{97}$ ), containing $97 \%$ polyphenols $(38 \%$ EGCG) were obtained from Pharmanex LLC (Provo, UT). These extracts were dissolved in sterile water at a concentration of $50 \mathrm{mg} / \mathrm{ml}$ and stored at $4^{\circ} \mathrm{C}$.

Cell culture. The human breast cancer cells MDA-MB-231 were obtained from ATCC (Manassas, VA) and were maintained in Dulbecco's modified Eagle's medium (DMEM) containing penicillin $(50 \mathrm{U} / \mathrm{ml})$, streptomycin $(50 \mathrm{U} / \mathrm{ml})$, and $10 \%$ fetal bovine serum (FBS). Media and supplements were from Invitrogen (Grand Island, NY). FBS was obtained from Hyclone (Logan, UT).

Cell proliferation (anchorage-dependent growth). MDA-MB231 cells $\left(2.5 \times 10^{3}\right)$ were cultured in a 96-well plate and treated for 24 and $48 \mathrm{~h}$ with GLE $(0-125 \mu \mathrm{g} / \mathrm{ml})$, GTE $(0-120 \mu \mathrm{g} / \mathrm{ml})$ or the combination of GLE and GTE as indicated in the text. Cell proliferation was determined by the tetrazolium salt method, as described (18). Data points represent mean \pm SD in one experiment repeated at least twice.

Colony formation (anchorage-independent growth). MDA-MB231 cells were harvested and seeded in 6-well plates coated with $1 \%$ agarose. Colony formation was assessed after incubation for 10-14 days with culture media with GLE (0-60 $\mu \mathrm{g}$ / $\mathrm{ml})$, GTE $(0-60 \mu \mathrm{g} / \mathrm{ml})$ or the combination of GLE and GTE, which was replaced every 4 days. Plates were stained with $0.005 \%$ Crystal Violet, and the colonies were counted manually under a microscope and photographed (13).

Cell adhesion, migration, and invasion assays. MDA-MB-231 cells were treated with GLE $(0-500 \mu \mathrm{g} / \mathrm{ml})$, GTE $(0-125 \mu \mathrm{g} / \mathrm{ml})$ or the combination of GLE and GTE. Cell adhesion was performed with Cytomatrix adhesion strips coated with human vitronectin (Chemicon International, Temecula, CA) as previously described (19). Cell migration of MDA-MB-231 cells was assessed in Transwell chambers in the DMEM medium containing $10 \%$ FBS, as previously described (13). Invasion of MDA-MB-231 cells treated with GLE (0-500 $\mu \mathrm{g} /$ $\mathrm{ml}$ ) and $30 \mu \mathrm{g} / \mathrm{ml}$ GTE was assessed in Transwell chambers coated with $100 \mu 1$ of Matrigel ${ }^{\mathrm{TM}}$ (BD Biosciences, Bedford, MA) diluted 1:4 with DMEM, after $72 \mathrm{~h}$ of incubation as described (13).

uPA secretion. DMEM media from MDA-MB-231 cells treated with GLE $(0-250 \mu \mathrm{g} / \mathrm{ml})$, GTE $(0-20 \mu \mathrm{g} / \mathrm{ml})$ or the combination of GLE and GTE for $24 \mathrm{~h}$ were collected and concentrated, and the secretion of uPA was detected by Western blot analysis with anti-uPA antibody (Oncogene Research Products, Cambridge, MA), as described (20).

Western blot analysis. Whole cell extracts were prepared from MDA-MB-231 cells treated with GLE $(0-8 \mu \mathrm{g} / \mathrm{ml})$, GTE $(0-60 \mu \mathrm{g} / \mathrm{ml})$ or the combination of GLE and GTE for $24 \mathrm{~h}$ as previously described (14). Equal amounts of proteins (20 $\mu \mathrm{g} /$ lane) were separated on NuPAGE 4-12\% Bis-Tris gel (Invitrogen, Carlsbad, CA) and transferred to a PVDF membrane (Millipore, Bedford, MA). The protein expression was detected with anti-c-myc antibody and anti- $\beta$-actin antibody (Santa Cruz Biotechnology, Santa Cruz, CA), and visualized using the ECL Western blotting detection system (Amersham Biosciences, Buckinghamshire, UK).

Statistical analysis. Data are presented as means \pm SD. Statistical comparison between the control group $(0 \mu \mathrm{g} / \mathrm{ml}$ of GLE and GTE) and groups with different GLE and GTE doses were analyzed by Student's t-tests. The value of $\mathrm{p}<0.05$ was considered to be significant.

\section{Results}

Green tea extract increases anti-proliferative effect of $G$. lucidum. The inhibition of proliferation of a variety of cancer cells by green tea or its major polyphenolic constituent EGCG has been demonstrated in numerous studies (3). In the present study we evaluated GTE containing $97 \%$ of polyphenols with $38 \%$ of EGCG on highly invasive breast cancer cells. MDAMB-231 cells were treated with GTE $(0-120 \mu \mathrm{g} / \mathrm{ml})$ for 24 and $48 \mathrm{~h}$ and cell proliferation was determined as described in Materials and methods. As seen in Fig. 1A, GTE markedly suppressed the proliferation of MDA-MB-231 cells in a doseand time-dependent manner. Since we have also recently demonstrated that $G$. lucidum inhibits the proliferation of MDA-MB-231 cells in a dose-dependent manner (0-250 $\mu \mathrm{g}$ / $\mathrm{ml}$ ), we hypothesized that GTE would enhance the effect of GLE on breast cancer cells. Therefore, MDA-MB-231 cells were treated with GLE $(0-125 \mu \mathrm{g} / \mathrm{ml})$ in the presence of 0,30 and $60 \mu \mathrm{g} / \mathrm{ml}$ of GTE for 24 and $48 \mathrm{~h}$. Although GLE itself suppressed the proliferation of MDA-MB-231 cells by $23 \%$ (30 $\mu \mathrm{g} / \mathrm{ml} \mathrm{GLE}), 44 \%(60 \mu \mathrm{g} / \mathrm{ml} \mathrm{GLE})$ and $47 \%(125 \mu \mathrm{g} / \mathrm{ml}$ GLE), addition of $30 \mu \mathrm{g} / \mathrm{ml}$ of GTE increased this inhibition by 51,68 and $70 \%$, and addition of $60 \mu \mathrm{g} / \mathrm{ml}$ of GTE further increased the inhibition of proliferation by 60,73 and $77 \%$, respectively (Fig. 1B, only data for $24 \mathrm{~h}$ are shown). Finally, the low concentration $(0.25-8 \mu \mathrm{g} / \mathrm{ml})$ of GLE inhibits the proliferation of MDA-MB-231 cells by 6-39\% (Fig. 1C), and addition of $30 \mu \mathrm{g} / \mathrm{ml} \mathrm{GTE}$ further increased this inhibition by $19-51 \%$, respectively (Fig. 1D).

Combined effects of green tea and G. lucidum on colony formation. The formation of colonies of cancer cells in vitro (anchorage-independent growth) is comparable with tumorigenesis in vivo (21). Because our previous study demonstrated that G. lucidum $(250-500 \mu \mathrm{g} / \mathrm{ml})$ suppresses the colony formation of highly invasive breast cancer cells (13), we assessed the effect of GTE, GLE and combination of GTE and GLE on anchorage-independent growth of MDA-MB- 
$\mathbf{A}$

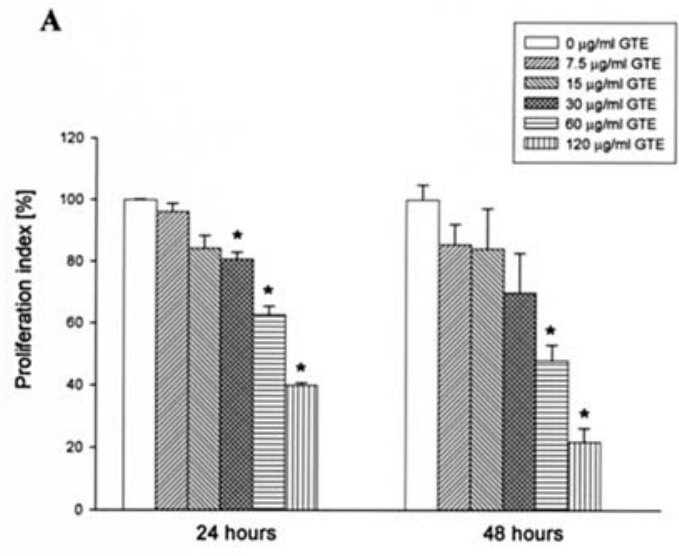

c

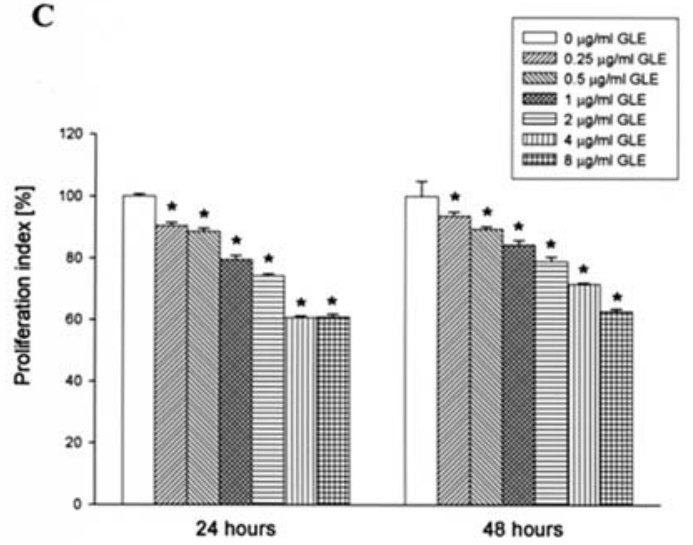

B

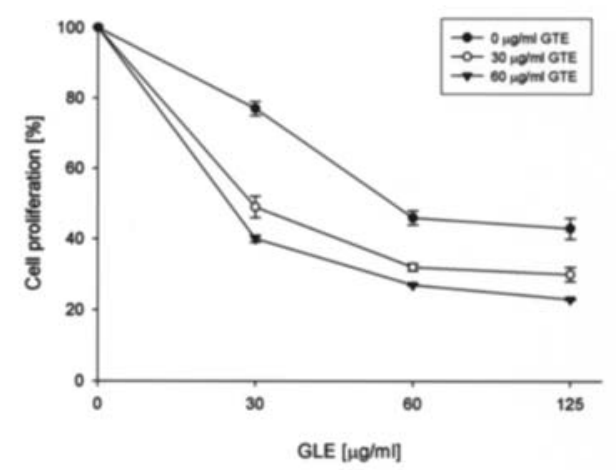

D

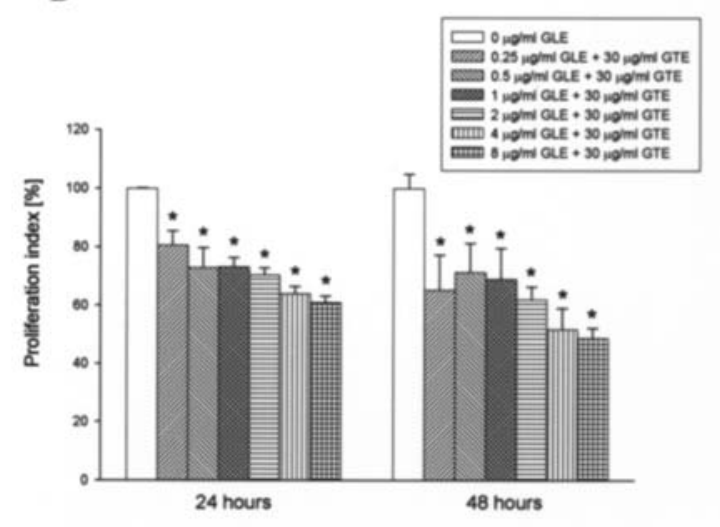

Figure 1. Green tea extract and G. lucidum extract inhibited the proliferation of breast cancer cells. MDA-MB-231 cells were treated with (A) GTE (0-120 $\mu \mathrm{g} / \mathrm{ml})$ for 24 and $48 \mathrm{~h}$, (B) GLE (0-125 $\mu \mathrm{g} / \mathrm{ml})$ and GTE $(0-60 \mu \mathrm{g} / \mathrm{ml})$ for $24 \mathrm{~h}$, (C) GLE (0-8 $\mu \mathrm{g} / \mathrm{ml})$ for 24 and $48 \mathrm{~h}$, and (D) GLE (0-8 $\mu \mathrm{g} / \mathrm{ml})$ and $30 \mu \mathrm{g} / \mathrm{ml} \mathrm{GTE}$ for 24 and $48 \mathrm{~h}$. Proliferation was assessed, as described in Materials and methods. Each bar represents the mean \pm SD of three experiments. ${ }^{*} \mathrm{p}<0.05$ versus control.
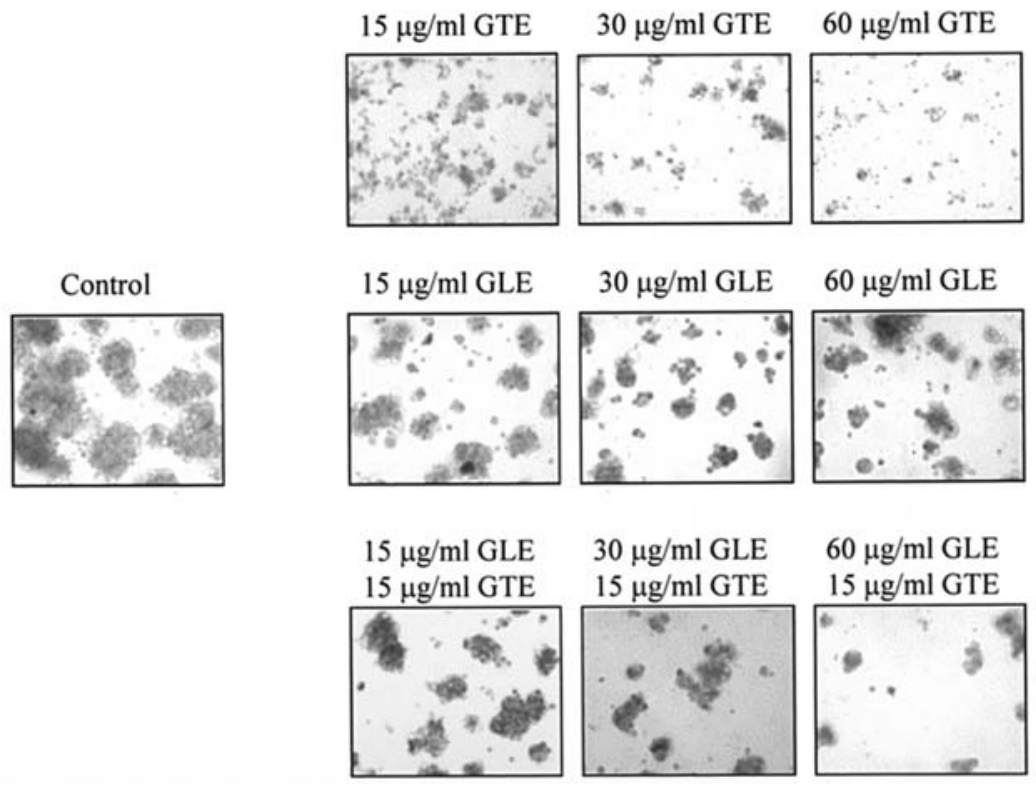

Figure 2. Green tea extract and G. lucidum extract suppressed the colony formation of MDA-MB-231 cells. MDA-MB-231 cells were harvested and seeded in 6-well plates coated with agarose in the presence of GTE $(0-60 \mu \mathrm{g} / \mathrm{ml})$, GLE $(0-60 \mu \mathrm{g} / \mathrm{ml})$, or the combination of GLE $(0-60 \mu \mathrm{g} / \mathrm{ml})$ and $15 \mu \mathrm{g} / \mathrm{ml}$ GTE. Anchorage-independent growth was assessed as described in Materials and methods. 
A

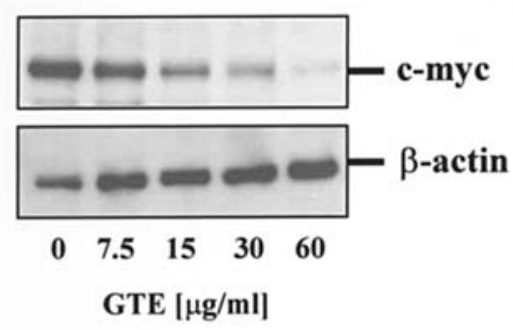

B

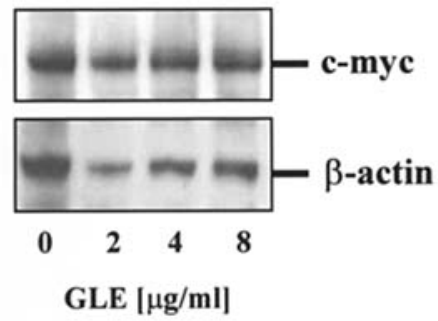

C

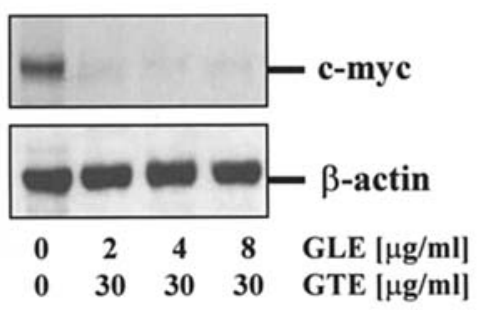

Figure 3. Effect of GTE and GLE on the expression of c-myc in breast cancer cells. MDA-MB-231 cells were treated with (A) GTE $(0-60 \mu \mathrm{g} / \mathrm{ml}),(\mathrm{B})$ GLE $(0-8 \mu \mathrm{g} / \mathrm{ml})$, and $(\mathrm{C})$ the combination of GLE $(0-8 \mu \mathrm{g} / \mathrm{ml})$ and $30 \mu \mathrm{g} / \mathrm{ml} \mathrm{GTE}$ for $24 \mathrm{~h}$. Whole cell extracts were subjected to Western blot analysis with anti-c-myc antibody. The equal protein loading was verified with anti- $\beta$-actin as described in Materials and methods. The results are representative of three separate experiments.

Table I. Adhesion of MDA-MB-231 cells to vitronectin.

\begin{tabular}{lccr}
\hline & $\begin{array}{c}\text { GTE } \\
(0 \mu \mathrm{g} / \mathrm{ml})\end{array}$ & $\begin{array}{c}\text { GTE } \\
(30 \mu \mathrm{g} / \mathrm{ml})\end{array}$ & $\begin{array}{c}\text { GTE } \\
(60 \mu \mathrm{g} / \mathrm{ml})\end{array}$ \\
\hline GLE $(0 \mu \mathrm{g} / \mathrm{ml})$ & $100 \pm 4.8$ & $24 \pm 1.1^{\mathrm{a}}$ & $7 \pm 1.7^{\mathrm{a}}$ \\
GLE $(125 \mu \mathrm{g} / \mathrm{ml})$ & $55 \pm 4.8^{\mathrm{a}}$ & $20 \pm 3.7^{\mathrm{a}}$ & $2 \pm 1.1^{\mathrm{a}}$ \\
GLE $(250 \mu \mathrm{g} / \mathrm{ml})$ & $45 \pm 2.4^{\mathrm{a}}$ & $13 \pm 9.2^{\mathrm{a}}$ & $1.5 \pm 0.6^{\mathrm{a}}$ \\
GLE $(500 \mu \mathrm{g} / \mathrm{ml})$ & $27 \pm 9.8^{\mathrm{a}}$ & $10 \pm 6.2^{\mathrm{a}}$ & $0.3 \pm 0.2^{\mathrm{a}}$ \\
\hline
\end{tabular}

Adhesion is expressed as $\%$ of cells which bind to vitronectin coated strips. ${ }^{a} \mathrm{p}<0.05$ versus control $(0 \mu \mathrm{g} / \mathrm{ml}$ GLE, $0 \mu \mathrm{g} / \mathrm{ml} \mathrm{GTE})$.

231 cells. As seen in Fig. 2, MDA-MB-231 cells formed colonies on $1 \%$ agarose after 14 days of incubation (control), whereas GTE $(15,30$ and $60 \mu \mathrm{g} / \mathrm{ml})$ markedly suppressed colony formation. Although GLE (15, 30 and $60 \mu \mathrm{g} / \mathrm{ml})$ only slightly decreased the colony formation of MDA-MB-231 cells, the combination of GLE and GTE demonstrated a distinctly more inhibitory effect than separated GLE or GTE (Fig. 2). Therefore, green tea extract and G. lucidum extract synergistically inhibited the colony formation of invasive human breast cancer cells.

Combination of green tea and G. lucidum down-regulate expression of c-myc in breast cancer cells. High proliferative potential of breast cancer cells is associated with the increased expression of the oncogene c-myc $(22,23)$. As recently demonstrated, EGCG suppressed c-myc mRNA, and G. lucidum down-regulated expression of c-myc protein in MDA-MB-231 cells, respectively $(24,25)$. Therefore, we hypothesized that the suppression of proliferation and colony formation by GTE and GLE in breast cancer cells is modulated by the down-regulation of expression of c-myc. MDA-MB-231 cells were treated with GTE $(0-60 \mu \mathrm{g} / \mathrm{ml})$ for $24 \mathrm{~h}$ and the expression of c-myc was evaluated by Western blot analysis as described in Materials and methods. As seen in Fig. 3A, GTE markedly decreased expression of c-myc in a dose-response manner. Since we have recently demonstrated the down-regulation of c-myc expression with $250 \mu \mathrm{g} / \mathrm{ml}$ of $G$. lucidum extract (25), and as GLE started to inhibit proliferation at the lower concentration (Fig. 1C), we evaluated if GLE $(0-8 \mu \mathrm{g} / \mathrm{ml})$ would also down-regulate expression of c-myc in MDA-MB231 cells. However, GLE at the low concentration did not significantly decrease expression of c-myc (Fig. 3B), whereas the combination of GTE and GLE clearly down-regulated expression of c-myc in MDA-MB-231 cells (Fig. 3C).

Combined effects of green tea and G. lucidum on invasive behavior of breast cancer cells. We have previously demonstrated that G. lucidum and green tea polyphenols inhibit adhesion, migration and invasion of highly invasive breast cancer cells (13-17). In order to investigate whether invasive behavior could be suppressed by the combination of G. lucidum and green tea, cell adhesion, cell migration and cell invasion of MDA-MB-231 cells was assessed in the presence of GLE and GTE. Although the sole GLE $(0-500 \mu \mathrm{g} / \mathrm{ml})$ or GTE $(0-60 \mu \mathrm{g} / \mathrm{ml})$ suppresses adhesion of MDA-MB-231 cells to the extracellular matrix protein vitronectin in a dose-response manner, combination of GLE and GTE demonstrated a synergistic effect in the inhibition of cell adhesion (Table I). Next we evaluated the effect of GLE and GTE on migration of MDA-MB-231 cells. As expected the individual GTE suppresses migration of MDA-MB-231 cells in a dose-response manner by 13,25 and $38 \%$ for 30,60 and $125 \mu \mathrm{g} / \mathrm{ml}$ of GTE, respectively, and GLE inhibits migration by 48,63 and $74 \%$ for 125,250 and $500 \mu \mathrm{g} / \mathrm{ml}$, respectively. Nevertheless, the combination of GLE and GTE synergistically inhibits the migration of invasive breast cancer cells (Table II). Because the proteolytic activity of cancer cells reflects their invasiveness by the degradation of extracellular matrix (ECM) components, we investigated whether the addition of GTE enhances the inhibitory effect of GLE on invasion of MDAMB-231 cells through Matrigel. As seen in Fig. 4, although GLE markedly suppressed the invasion of MDA-MB-231 
Table II. Combined effect of GLE and GTE on migration of MDA-MB-231 cells.

\begin{tabular}{|c|c|c|c|c|}
\hline & GTE $(0 \mu \mathrm{g} / \mathrm{ml})$ & GTE $(30 \mu \mathrm{g} / \mathrm{ml})$ & GTE $(60 \mu \mathrm{g} / \mathrm{ml})$ & GTE $(125 \mu \mathrm{g} / \mathrm{ml})$ \\
\hline GLE $(0 \mu \mathrm{g} / \mathrm{ml})$ & $100 \pm 2.4$ & $87 \pm 2.4^{\mathrm{a}}$ & $75 \pm 2.5^{\mathrm{a}}$ & $62 \pm 4.3^{\mathrm{a}}$ \\
\hline GLE $(125 \mu \mathrm{g} / \mathrm{ml})$ & $54 \pm 3.9^{\mathrm{a}}$ & $46 \pm 1.9^{\mathrm{a}}$ & $43 \pm 2.0^{\mathrm{a}}$ & $38 \pm 4.0^{\mathrm{a}}$ \\
\hline GLE $(250 \mu \mathrm{g} / \mathrm{ml})$ & $37 \pm 1.3^{\mathrm{a}}$ & $36 \pm 2.0^{\mathrm{a}}$ & $31 \pm 4.6^{\mathrm{a}}$ & $22 \pm 3.3^{\mathrm{a}}$ \\
\hline GLE $(500 \mu \mathrm{g} / \mathrm{ml})$ & $26 \pm 2.8^{\mathrm{a}}$ & $21 \pm 1.3^{\mathrm{a}}$ & $19 \pm 1.8^{\mathrm{a}}$ & $16 \pm 2.4^{\mathrm{a}}$ \\
\hline
\end{tabular}

Migration is expressed as $\%$ of cells, which migrated through the filters in Boyden chambers. ${ }^{\mathrm{a}} \mathrm{p}<0.05$ versus control $(0 \mu \mathrm{g} / \mathrm{ml} \mathrm{GLE}, 0 \mu \mathrm{g} / \mathrm{ml}$ GTE).

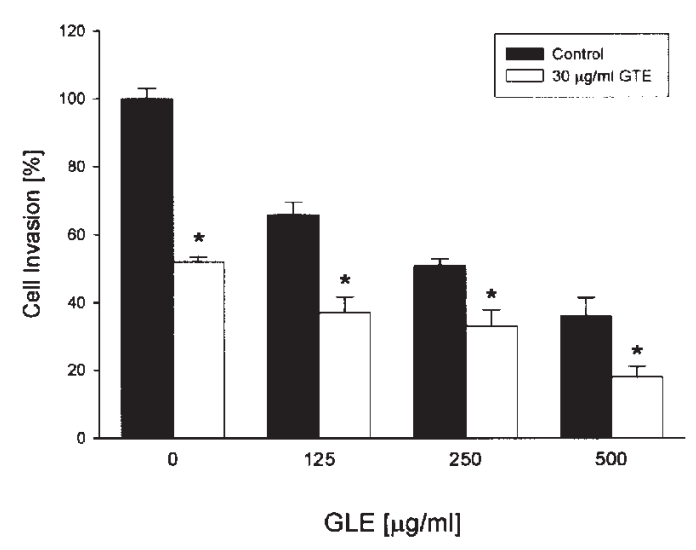

Figure 4. Combined effect of GLE and GTE on invasion of MDA-MB-231 cells. MDA-MB-231 cells were harvested and treated with GLE $(0-500 \mu \mathrm{g} / \mathrm{ml})$ and $30 \mu \mathrm{g} / \mathrm{ml} \mathrm{GTE}$. Invasion through Matrigel was assessed after $72 \mathrm{~h}$ of incubation as described in Materials and methods. Data are the means \pm SD of triplicate determinations. Similar results were obtained in at least two additional experiments. ${ }^{*} \mathrm{p}<0.05$ versus control.

A

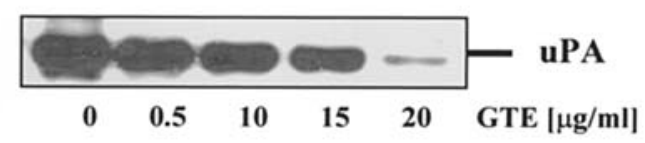

B

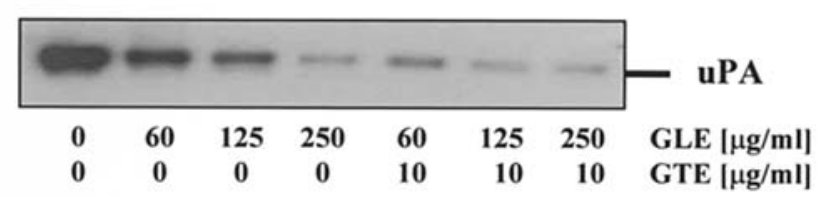

Figure 5. Combined effect of GLE and GTE on uPA secretion. Medium from MDA-MB-231 cells treated with (A) GTE $(0-20 \mu \mathrm{g} / \mathrm{ml})$, (B) GLE $(0-250 \mu \mathrm{g} / \mathrm{ml})$ and $\operatorname{GTE}(0,10 \mu \mathrm{g} / \mathrm{ml})$ for $24 \mathrm{~h}$ was concentrated as described in Materials and methods. Secretion of uPA was detected by Western blot analysis with anti-uPA antibody. The results are representative of three separate experiments.

cells, the addition of $30 \mu \mathrm{g} / \mathrm{ml}$ of GTE further increased the inhibition of invasion of MDA-MB-231 cells. Taken together, green tea extract increases the anti-invasive effect of G. lucidum extract on breast cancer cells.
Combination of green tea and G. lucidum suppressed the secretion of UPA from breast cancer cells. Since uPA plays a crucial role in the cell adhesion, migration and invasion (26), we evaluated if the combination of GLE and GTE suppresses secretion of uPA from highly invasive breast cancer cells. Conditioned medium from MDA-MB-231 cells treated with GTE $(0-20 \mu \mathrm{g} / \mathrm{ml})$ for $24 \mathrm{~h}$ was collected and subjected to Western blot analysis with anti-uPA antibody. As seen in Fig. 5A, GTE suppresses secretion of uPA in a dose-response manner. uPA secretion was also inhibited from cells treated with GLE (0-125 $\mu \mathrm{g} / \mathrm{ml})$, and this effect was further enhanced by the addition of $10 \mu \mathrm{g} / \mathrm{ml}$ of GTE (Fig. 5B). In summary, green tea extract enhances $G$. lucidum-dependent inhibition of secretion of uPA from highly invasive breast cancer cells.

\section{Discussion}

Uncontrolled proliferation and increased invasive potential of cancer cells usually result in cancer metastasis. Therefore, natural/dietary compounds with anti-proliferative and antiinvasive capacity are suitable agents for cancer prevention. Several in vitro and in vivo studies demonstrated the chemopreventative effect of green tea, and its major compound, EGCG, was identified as one of the major natural modulators of signaling pathways involved in cancer progression (3). Other studies demonstrated the anticancer activity of medicinal mushroom G. lucidum, and its extracts, containing triterpenes and polysaccharides, suppressed signaling responsible for the invasive behavior of cancer cells (27). In the present study, we evaluated the combined effect of green tea extract (GTE, a green tea leaf extract standardized to contain $97 \%$ polyphenols with $38 \%$ of EGCG) and G. lucidum extract (GLE, a G. lucidum powdered extract with cracked spores standardized to $13.5 \%$ polysaccharides and $6 \%$ triterpenes) on highly invasive and metastatic breast cancer cells.

GTE increased the anti-cancer effect of GLE on the anchorage-dependent (cell proliferation) as well as anchorageindependent (colony formation) growth of breast cancer cells. This effect can be mediated, in part, by the inhibition of oncogene c-myc because GTE, and especially the combination of GTE and GLE, down-regulated the expression of c-myc in MDA-MB-231 cells. Although individual GTE and GLE independently inhibited the adhesion, migration and invasion of MDA-MB-231 cells, their combination demonstrated a synergistic effect, which was mediated by the suppression of secretion of uPA from breast cancer cells. 
Our observation is in agreement with the generally accepted concept that the combination of different bioactive agents and/or food factors could increase the cancer preventative effects of a single constituent $(28,29)$. As previously demonstrated, the combination of EGCG with a non-steroidal antiinflammatory drug (NSAID) sulindac (30), or the combination of EGCG with phytic acid from grain (31), synergistically suppressed preneoplastic lesions in a rat colon carcinogenesis model. Furthermore, the combination of grape skin extract with green tea infusion (containing 50\% EGCG) inhibited the growth of 4T1 mouse tumors in vivo, and suppressed the viability of human cervical cancer cells (HeLa) in vitro (32). Finally, the combination of soy phytochemical concentrate with green tea infusion (containing 38\% EGCG) inhibited the growth of human breast cancer cells in mice through the suppression of cell proliferation (33).

In this study we demonstrate, for the first time, that the combination of green tea and G. lucidum extracts inhibits the growth of breast cancer cells. This inhibition of proliferation of MDA-MB-231 is mediated by the down-regulation of expression of c-myc by the combined effect of GLE and GTE. In agreement with a recent report describing decrease of c-myc RNA levels by EGCG (24), GTE also markedly suppressed expression of c-myc in MDA-MB-231 cells. Although a GLE concentration of $250 \mu \mathrm{g} / \mathrm{ml}$ previously inhibited expression of c-myc in breast cancer cells (25), a low concentration of GLE $(0-8 \mu \mathrm{g} / \mathrm{ml})$ did not affect its expression (Fig. 3B). Nevertheless, the combination treatment of a low concentration of GLE and GTE markedly suppressed expression of c-myc in MDA-MB-231 cells.

The combination of GLE and GTE inhibited cell invasiveness as assessed by the suppression of cell adhesion, migration and invasion of breast cancer cells. This effect was caused by the suppression of secretion of uPA from MDA-MB-231 cells. Since the increased levels of uPA correspond to highly metastatic cancers in breast cancer patients, and are associated with poor prognosis and outcome (34), the inhibition of secreted uPA from invasive breast cancer cells by GLE and GTE has potential clinical application. Although G. lucidum and green tea extracts can inhibit invasiveness through the suppression of uPA secretion independently $(12,17)$, their synergistic effect requires markedly low doses of individual compounds.

In conclusion, the present study demonstrated the synergistic effect of GLE and GTE in the inhibition of growth and invasive behavior of highly metastatic breast cancer cells. Further studies are necessary to elucidate if the combination of G. lucidum and green tea extracts as a dietary supplement is suitable for breast cancer chemoprevention and/or treatment.

\section{Acknowledgements}

This work was supported by the Pharmanex LLC of Nu Skin International Inc.

\section{References}

1. Jemal A, Murray T, Ward E, Samuels A, Tiwari RC, Ghafoor A, Feuer EJ and Thun MJ: Cancer statistics. CA Cancer J Clin 55: 10-30, 2005.
2. Glade MJ: Food, nutrition and the prevention of cancer: a global perspective. American Institute for Cancer Research/World Cancer Research Fund. Am Inst Cancer Res 6: 241-245, 1997.

3. Khan N, Afaq F, Saleem M, Ahmad N and Mukhtar H: Targeting multiple signaling pathways by green tea polyphenol (-)-epigallocatechin-3-gallate. Cancer Res 66: 2500-2505, 2006.

4. Kim HJ, Chang WK, Kim MK, Lee SS and Choi BY: Dietary factors and gastric cancer in Korea: a case-control study. Int J Cancer 97: 531-535, 2002.

5. Klaunig JE, Xu Y, Isenberg JS, Bachowski S, Kolaja KL, Jiang J, Stevenson DE and Walborg EF Jr: The role of oxidative stress in chemical carcinogenesis. Environ Health Perspect 106: 289-295, 1998.

6. Pezzuto JM, Kosmeder JW II, Park EJ, Lee SK, Cuendet M, Gills J, Bhat K, Grubjesic S, Park HS, Mata-Greenwood E, Tan YM, Yu R, Lantvit DD and Kinghorn AD: Characterization of natural product chemopreventive agents. In: Cancer Chemoprevention, Vol. 2: Strategies for Cancer Chemoprevention. Kelloff GJ, Hawk ET and Sigman CC (eds). Humana Press Inc., Totowa, NJ, pp3-37, 2005.

7. Liu X, Yuan JP, Chung CK and Chen XJ: Antitumor activity of the sporoderm-broken germinating spores of Ganoderma lucidum. Cancer Lett 182: 155-161, 2002.

8. Yun TK, Kim SH and Lee YS: Trial of a new medium-term model using benzo(a)pyrene induced lung tumor in newborn mice. Anticancer Res 15: 839-845, 1995.

9. Lu H, Kyo E, Uesaka T, Katoh O and Watanabe H: Prevention of development of N,N'-dimethylhydrazine-induced colon tumors by a water-soluble extract from cultured medium of Ganoderma lucidum (Rei-shi) mycelia in male ICR mice. Int J Mol Med 9: 113-117, 2002.

10. Kimura Y, Taniguchi M and Baba K: Antitumor and antimetastatic effects on liver of triterpenoid fractions of Ganoderma lucidum: mechanism of action and isolation of an active substance. Anticancer Res 22: 3309-3318, 2002.

11. Yuen JWM and Gohel MDI: Anticancer effects of Ganoderma lucidum: a review of scientific evidence. Nutr Cancer 53: 11-17, 2005.

12. Sliva D, Labarrere C, Slivova V, Sedlak M, Lloyd FP Jr and Ho NWY: Ganoderma lucidum suppresses motility of highly invasive breast and prostate cancer cells. Biochem Biophys Res Commun 298: 603-612, 2002.

13. Slivova V, Valachovicova T, Jiang J and Sliva D: Ganoderma lucidum inhibits invasiveness of breast cancer cell. J Cancer Integr Med 2: 25-30, 2004.

14. Jiang J, Slivova V, Harvey K, Valachovicova T and Sliva D: Ganoderma lucidum suppresses growth of breast cancer cells through the inhibition of Akt/NF-kB signaling. Nutr Cancer 49: 209-216, 2004.

15. Mukhtar H and Ahmad N: Tea polyphenols. Prevention of cancer and optimizing health. Am J Clin Nutr 71: 1698-1702, 2000.

16. Yang CS, Maliakal P and Meng X: Inhibition of carcinogenesis by tea. Annu Rev Pharmacol Toxicol 42: 25-54, 2002.

17. Slivova V, Zaloga G, De Michele SJ, Mukerji P, Huang YS, Siddiqui R, Harvey K, Valachovicova T and Sliva D: Green tea polyphenols modulate secretion of urokinase plasminogen activator (uPA) and inhibit invasive behavior of breast cancer cells. Nutr Cancer 52: 65-72, 2005.

18. Jiang J, Slivova V, Valachovicova T, Harvey K and Sliva D: Ganoderma lucidum inhibits proliferation and induces apoptosis in human prostate cancer cells PC-3. Int J Oncol 24: 1093-1099, 2004.

19. Lloyd FP Jr, Slivova V, Valachovicova T and Sliva D: Aspirin inhibits highly invasive prostate cancer cells. Int J Oncol 23: 1277-1283, 2003.

20. Sliva D, Rizzo MT and English D: Phosphatidylinositol 3-kinase and NF- $\mathrm{B}$ regulate motility of invasive MDA-MB-231 human breast cancer cells by the secretion of urokinase-type plasminogen activator (uPA). J Biol Chem 277: 3150-3157, 2002.

21. Freedman VH and Shin SI: Cellular tumorigenicity in nude mice: correlation with cell growth in semi-solid medium. Cell 3: 355-359, 1974.

22. Liao DJ and Dickson RB: c-Myc in breast cancer. Endocr Relat Cancer 7: 143-164, 2000.

23. Kim DW, Sovak MA, Zanieski G, Nonet G, Romieu-Mourez R, Lau AW, Hafer LJ, Yaswen P, Stampfer M, Rogers AE, Russo J and Sonenshein GE: Activation of NF-kappaB/Rel occurs early during neoplastic transformation of mammary cells. Carcinogenesis 21: 871-879, 2000. 
24. Kim J, Zhang X, Rieger-Christ KM, Summerhayes IC, Wazer DE, Paulson KE and Yee AS: Suppression of Wnt Signaling by the green tea compound (-)-epigallocatechin 3-gallate (EGCG) in invasive breast cancer cells: requirement of the transcriptional repressor HBP1. J Biol Chem 281: 10865-10875, 2006.

25. Jiang J, Slivova V and Sliva D: Ganoderma lucidum inhibits proliferation of human breast cancer cells by down-regulation of estrogen receptor and NF-кB signaling. Int J Oncol 29: 695-704, 2006.

26. Blasi F and Carmeliet P: uPAR: a versatile signaling orchestrator. Nat Rev Mol Cell Biol 3: 932-943, 2002.

27. Sliva D: Ganoderma lucidum (Reishi) in cancer treatment. Integr Cancer Ther 2: 358-364, 2003.

28. Chemoprevention Working Group: Prevention of cancer in the next millennium: report of the chemoprevention working group to the American Association for Cancer Research. Cancer Res 59: 4743-4758, 1999.
29. Ohigashi $\mathrm{H}$ and Murakami A: Cancer prevention with food factors: alone and in combination. Biofactors 22: 49-59, 2004.

30. Ohishi T, Kishimoto Y, Miura N, Shiota G, Kohri T, Hara Y, Hasegawa J and Isemura M: Synergistic effects of (-)-epigallocatechin gallate with sulindac against colon carcinogenesis of rats treated with azoxymethane. Cancer Lett 177: 49-56, 2002.

31. Challa A, Rao DR and Reddy BS: Interactive suppression of aberrant crypt foci induced by azoxymethane in rat colon by phytic acid and green tea. Carcinogenesis 18: 2023-2026, 1997.

32. Morre DM and Morre DJ: Anticancer activity of grape and grape skin extracts alone and combined with green tea infusions. Cancer Lett 238: 202-209, 2006.

33. Zhou JR, Yu L, Mai Z and Blackburn GL: Combined inhibition of estrogen-dependent human breast carcinoma by soy and tea bioactive components in mice. Int J Cancer 108: 8-14, 2004.

34. Duffy MJ: The urokinase plasminogen activator system: role in malignancy. Curr Pharm Des 10: 39-49, 2004. 